\title{
Practical Approach to Sustainable Food Security in Lower Income Group Countries
}

\author{
Oluwatoyin Oluwole*, Adebukola Agboola, Olubunmi Ibidapo, Olajumoke Odediran, Deborah Ibekwe and Joy \\ Onyibe \\ Department Food Technology, Federal Institute of Industrial Research Oshodi, Nigeria
}

Submission: February 06, 2017; Published: February 27, 2017

*Corresponding author: Oluwatoyin Oluwole, Department Food Technology, Federal Institute of Industrial Research Oshodi, Lagos, Nigeria, Tel: +234803-304-4961; Email: oluwatoyinoluwole575@yahoo.com

\section{Summary}

Over the years, steady progress have been made in the fight to end global hunger and food insecurity, however, the number of undernourished people in the world is still unacceptably high, particularly in countries with low economies. The challenging global environment- rising commodity and food prices, increased unemployment rates and most importantly the global economic recession - has taken its toll on the considerable progress that could have been made in the food security campaign. In addition, frequent natural disasters with consequent loss of human lives and economic damage, and increased political instability leading to displacement of persons have also contributed to the food insecurity menace. In the light of the above, more work needs to be done to ensure everyone, everywhere has access to adequate food to maintain an active and healthy lifestyle. In pursuance of this however, food production process must not deplete natural resources or hinder the agricultural system such that provision of food for future generation will be difficult. Thus, interventions towards ensuring food security must consider sustainability. This paper discusses such sustainable drivers of food security, particularly in lower income group countries where the burden of hunger and undernourishment are particularly high.

\section{Introduction}

Food security exists when "all people at all times have physical, social and economic access to sufficient, safe and nutritious food that meets their dietary needs and food preferences for an active and healthy lifestyle" [1]. Food security rests on the basis that food must be available, accessible (physical and economic access), adequately utilised (including being safe and of good quality) and stable (in supply and access).

It is also important that everyone around the world is food secure both in the short term and long term. It is necessary to ensure that food is sufficiently available for current and future generations, with sustainable methods of production and distribution, such that current available resources are used in ways that do not compromise or preclude future production and distribution of food. These are the conditions on which the campaign for sustainable food security hinges.

The year 2015 marked the end of monitoring for the millennium development goals - one of which was "halving the proportion of chronically undernourished people" that is, MDG 1c. Prevalence of undernourishment and proportion of underweight among children less than 5 years old were key indicators used in measuring MDG 1c. Figures showed that even though the proportion of undernourished people decreased from $15 \%$ in $2000-02$ to $11 \%$ in 2014-16, millions of people are still food insecure globally. According to the Food and Agriculture Organization statistics, between 2014-2016, approximately 795 million people are estimated to be undernourished around the world, with the highest burden being in South Asia - 281 million and Sub-Saharan Africa - 220 million [2]. It should be noted that most of the countries in these geographical regions have been classified by the World Bank as either low income countries with gross national income (GNI) per capita of $\$ 1,025$ or less, or lower middle income countries with GNI of between $\$ 1,026$ and $\$ 4,035$ World Bank [3].

Figures from nationally representative household consumption surveys and anthropometric measures, which are other methods for measuring food insecurity, also show a gloomy outlook for countries in lower income groupings. Stunting (defined as low height for age) for example, is an anthropometric indicator of chronic hunger/long term food insecurity. Statistics show that $37.6 \%$ and $33.5 \%$ of children less than 5 years old in low-income countries and lower-middle income countries respectively are stunted. Compared with 1990, the share of stunted children that live in lower-income group countries has increased from 7-in-10 to 9-in-10 in 2014 [4]. Micronutrient deficiency (hidden huger) also affect a considerable number of persons world-wide - over 2 billion people are deficient in the key 
micronutrients, that is, vitamin A, iron, iodine and zinc, with resulting impairment in cognitive and mental development [2].

Poor economic growth, natural/human-induced disasters and political instability are some of the underlying factors that have induced hunger and invariably, undernourishment in these regions. It has been estimated that the world population will increase to about 9.3 billion by 2050 , with most of the increase occurring in lower income group countries and in order to feed this increased population, food production must also simultaneously increase by $70 \%$ FAO [5] - though in a sustainable fashion. In view of these, it is important to commit to the newly adopted sustainable development goals which among it is - "to end hunger, achieve food security and improved nutrition and promote sustainable agriculture". To achieve the desired results by the target year 2030, practical and measurable steps thus must be taken by all stakeholders involved in the food security campaign

\section{Proposed Practical Approach to Sustainable Food Security \\ Improving the food value chain}

Various challenges across the food value chain have contributed to food insecurity in many low income countries. Quality of inputs, low productivity and non-demand linked production are some of the challenges faced by producers. In the processing stages, low processing, lack of quality products, poor returns and low capacity utilisation are some of the key issues faced. In the supply chain, Poor transportation and road network, and lack of good storage facilities leading to wastes and losses are the main problems.

Post-harvest losses and food waste account for as high as $33 \%$ in the food supply chain [6]. Post harvest handling conditions are particularly poor in low income countries. Causes of food deterioration, and invariably, losses, in these countries are a combination of biological, environmental and physical factors. The hot, humid air and atmospheric compositions of some of these countries can speed up the rate of internal deterioration of harvested products. Moreover, insect and rodent infestation of stored food products, particularly grains and cereals, leads to substantive wastes yearly.

Use of improved cultivars with longer post-harvest life which can enhance yield and productivity; use of integrated crop management systems that allows for maximum yield and quality; and use of proper post-harvest handling techniques that maintains quality and safety of products are some of the strategies for reducing food losses. Also, the use of improved water- and labour-saving technologies, with a holistic approach to natural resource management should be considered. More practically, crops will have to be better driedfor better keeping, effective disinfestations and protection against re-infestation techniques has to be practised, proper sanitation to prevent microbial contamination has to be in place, and further to these, adequate storage and post-harvest transportation facilities must also be ensured. It should be noted that most food producers and handlers in these low income countries are small scale farmers, efforts need to be made by the government to equip them with tools, machines and equipment that help with better post harvest handling, and most importantly upgrade them to largescale farmers.

Reducing food losses can considerably increase food availability and significantly contribute to sustainable food security in these countries. Post harvest losses can however be minimized by adding value to agricultural crops right from the farm gate, employing appropriate technology for handling , preservation, storage and packaging of raw produce with improved handling techniques that will minimize rapid quality and physical deterioration of the produce for improved storage life of the raw produce as well as using appropriate processing techniques for the production of shelf stable nutritious, affordable, safe and wholesome food products acceptable by the ultimate consumer.

\section{Farm land expansion}

Countries in sub-Saharan Africa, Latin America and Southeast Asia have witnessed expansion in farmlands over the years due to strong agricultural commodity prices NRC [7]. This, arguably, have contributed to global food supply, but however not necessarily food security. In regions such as sub-Saharan Africa where land tenure and titling are not well defined, land-grabbing and transfer from traditional users to more "sophisticated" users have resulted in conflicts and food insecurity among local communities. Also, conversion of tropical farmlands into industrial uses has negative environmental impacts. Moreover improper regulation of land sale by government lead to land speculations and it reduces economic benefits accrued to such land. In the light of the above, there must be clear changes in land governance, with adequate policies and institutional capacities backing such changes up to ensure better benefits from land ownership. Local rights to land ownership must be respected and in cases of transfer, this must be done voluntarily (and with compensation as deem fit) and not under coercion by the government. Regulation of land rights and governance will be key to ensuring sustainable food security in lower income group countries.

\section{Investment and funding of agriculture}

Insufficient funding of agriculture in developing economies has had a detrimental effect on their food security. There is need to create conditions for investments in primary agriculture in lower-income group countries. Hitherto, primary funding for agriculture has come from the public coffers - government institutions and agencies, it is high time private investors become interested in agricultural funding in order to boost agricultural production and for farmers in the lower income group countries, 
this may mean better access to capital, modern technology and a wider market base needed for improving crop production. Such investments should therefore focus on substituting manual labour with modern, capital-saving technology and equipment, providing transportation and market infrastructure, funding agricultural research and development including irrigation, and providing other productive assets. Moreover, developed economies should provide more official development assistance toward agriculture to the lower-income countries and engage in more foreign direct investment in their agriculture. In turn, the lower-income countries should improve on their investment climate by putting in place the right institutions to manage the investments and ensure stability for the investors and transparency in the use of funds.

\section{Agricultural extension services}

Poor agricultural extension and linkage programmes have also contributed to poor productivity among smallholder farmers. Skills and technology transfer need to be improved on. Information on new technologies, plant varieties and cultural should be regularly disseminated to these farmers. Information and communication technology (ICT) tools can be of immense importance in this regard. For example, some states in Nigeria provided mobile phones for rural farmers to communicate important information such as availability of fertilisers.

\section{Markets and international trade}

Many developing economies depend on international trade and imports for their food security. It is however imperative that lower-income group countries begin to look inwards and develop their trade and export market. It is also important that a global trading system that is fair and competitive is put in place to create a dependable market for food. In addition, greater market access and support should be provided for agricultural producers from developing countries so that they can compete on a fair footing.

In spite of the above, it is still however necessary that innovative arrangements are made to ensure global food stocks are adequate such that poor and dependent countries have access to them in time of unprecedented scarcity.

\section{Conclusion}

Though current figures and statistics measuring the state of global food insecurity may not look too assuring, several strategies are available to combating and ending the scourge. Necessary investment in agriculture (from both public funds and private investors), including agricultural research and development should be undertaken in addition to setting up policies favouring agricultural production. Crop yield and cropping intensity that would lead to increased production should be given much attention - this will include provision of modern technologies, improving the food value chain and expanding arable land. The global trade and market system to be conducted in ways that would support low income countries and provide a fair ground for their agricultural commodities to be sold.

There are indeed adequate resources to ensure long-term food security globally, however necessary institutions need to be set up and the political will to put these in place need to be mobilised to achieve results. There is no better time to act than now!

\section{References}

1. FAO (2002) The State of Food Insecurity in the World 2001. Rome, Italy.

2. FAO, IFAD, WFP (2015) The State of Food Insecurity in the World 2015. Meeting the 2015 international hunger targets: taking stock of uneven progress. Rome, Italy.

3. World Bank (2017) World Bank Country and lending groups.

4. UNICEF/WHO/World Bank (2015) Levels and trends in child malnutrition: joint child malnutrition estimates.

5. FAO (2009) How to Feed the World in 2050. Rome, Italy.

6. UNICEF/WHO/World Bank (2015) Levels and trends in child malnutrition: joint child malnutrition estimates.

7. National Research Council (NRC) (2012) A Sustainability Challenge: Food Security for All: Report of Two Workshops. National Academies Press, Washington, USA.

\section{Your next submission with Juniper Publishers will reach you the below assets}

- Quality Editorial service

- Swift Peer Review

- Reprints availability

- E-prints Service

- Manuscript Podcast for convenient understanding

- Global attainment for your research

- Manuscript accessibility in different formats ( Pdf, E-pub, Full Text, Audio)

- Unceasing customer service

Track the below URL for one-step submission https://juniperpublishers.com/online-submission.php 